\title{
Liquid Tumor
}

National Cancer Institute

\section{Source}

National Cancer Institute. Liquid Tumor. NCI Thesaurus. Code C116915.

A malignant tumor that originates from myeloid or lymphoid cells i.e., leukemias and lymphomas. 